\title{
THE ARCTIC ENVIRONMENT AND LEGISLATION
}

\author{
A. R. THOMPSON*
}

This is the first of three papers presented at the Tenth Annual Research Seminar on the special problems of the oil and gas industry in the Canadian Arctic. The paper examines the background to the industry's participation in the Arctic, the special problems of the Arctic environment, and the juris. dictional and administrative framework in the Yukon Territory, the Northwest Territories and the Northern offshore areas. In discussing the Arctic environment and legislation, the paper raises the question of whether or not there is a new environmental law, and suggests that there is a new environmental law taking shape which consists of demands for public participation in, and for a broad range of inquiry with respect to, the decision making processes in modern society.

\section{A. INTRODUCTION}

It is not easy to write a paper about law and the environmenteven when the environment is the Arctic and the focus is oil. At the root of the difficulty is the fact that we are not really sure that there is such a thing as "environmental law", although the phrase runs glibly through current issues of legal periodicals. One could provide a catalogue of new legislation, but more seems called for. There are basic questions to be asked. What are underlying reasons for today's obsession about the Arctic environment where only a few years ago the only things newsworthy north of sixty degrees were mad trappers and tales of starvation in the barren lands? Is a new "environmental law" taking shape? Or is it just the same old mix of crime, tort and government regulation under a new label? Are there new implications for lawyers? Can we foresee where these new developments will lead?

This new interest in the Arctic reflects the coalescence of a number of deeply-felt concerns on the part of North Americans. Firstly, the oil industry, itself, is under attack as never before. One only has to read the introductory pages of Richard O'Connor's new book, The Oil BaronsMen of Greed and Grandeur ${ }^{1}$ to find a disparging description of the oil industry that undoubtedly matches the image of the industry which many, and probably a majority, of informed Canadians and Americans have in their minds today. This fact sets the psychological tone for the Arctic oil phenomenon.

Secondly, accompanying this suspicion and distrust of the industry, is the current sense of environmental crisis that pervades our news media and therefore our public thoughts and attitudes. Some wishfully think of this crisis as ephemeral. After all, no crisis can continue unabated for long because the human psyche has built-in defence mechanisms that reduce stress by rationalizing crisis away. But this thought should be small comfort when there is daily evidence of new concerns to stimulate the sense of crisis. So long as health departments have to issue warnings about excessive air pollution and coliform counts, and against eating swordfish because of ninety per cent contamination by mercury, the environmental concerns will remain high on the list of public issues.

- LL.B. (Man.), LL.M. (Toronto), J.S.D. (Columbia). Professor of Law, University of British Columbia.

1. Little Brown \& Company, Boston, Mass., 1971. 
The oil industry's movement into the Mackenzie River basin and into the Arctic Islands has, by itself, introduced a new element into the picture. All through the fifties and for most of the sixties, the oil industry in Canada belonged to Alberta. Only the three Alberta newspapers carried news of the industry on a regular basis. Premier Manning and the Alberta Oil and Gas Conservation Board ran the show. There was a producing industry in Saskatchewan and a foray into northeastern British Columbia, but Alberta played an even more prominent role than Texas in the United States as the shaper of Canadian policies and practices in production and marketing. Once the National Energy Board was organized to provide housekeeping services for the pipelines and the "national oil policy" was established, federal interest in the industry was spent. After all, at this time the industry did not even pay income taxes! That has all changed-almost overnight in the industry's time scale. The northern and offshore lands are federally owned and administered. Ottawa has replaced Alberta as the industry's most important landlord. Not one, but two, Ottawa bureaucracies are gearing up to control the industry's producing side-one in the Department of Indian Affairs and Northern Development, for the northern lands and the high Arctic offshore areas, and the other in the Department of Energy, Mines and Resources, for the east and west coast and Hudson Bay offshore areas. The National Energy Board is being asked to chart new waters with respect to gas export and gas pricing, and Canadians, be they from Charlottetown or Nanaimo, are interested shareholders in the Panarctic venture. There is every likelihood that the oil industry in Canada will remain at centre stage in the theatre of Canadian public issues for a long time to come.

\section{B. THE ARCTIC ECOLOGY}

The final factor about this confrontation between oil and the environment is that the Arctic is, in truth, a special case. There are many reasons why this is so. The first, and probably the most obvious, is that the Arctic is a last, unexplored and unknown wilderness. There are pristine conditions where man can make a fresh start in his relationship with the land. This factor draws a broad distinction, in my way of thinking, between environmental issues in the north and in the south. In the south, these issues are issues of crowded cities, blighted landscapes and fouled rivers and streams, where energies must be directed to ways of abating pollution and remedying damage. In the north, the task is to plan to minimize disturbance from the beginning.

Part of this pristine environment are the indigenous people whose special problems impinge on our conscious concerns. It is no longer tolerable to establish a permanent settlement in the north as a supply base or a pipeline facility without careful study and consideration of its impact on native peoples. There is a slow-growing awareness among Canadians that the Indians and Eskimos have claims to land ownership in the north that must be satisfied. The Alaska experience shows how closely these claims are related to the land problems of the oil industry, and it is not impossible to imagine the construction of a pipeline across the Old Crow Flats being restrained by a Canadian court pending settlement of the native claims issue.

The Arctic is unique in an ecological sense, as oil industry people 
have been told so often. The energy-cycling process is dependent on such a small number of species of plants and animals compared with the situation in a temperate zone, that disturbance of even a single species is not readily compensated and can have far-reaching consequences. The generative process is, itself, so slow as to require eons of time, by southern standards, to repair damage done. The land mass over so much of the Arctic is so delicate in balance between conditions of ice and desert as to create anxiety about any disturbance of the northern thermostat.

Finally, the Arctic has a hold on human nature in some inexplicable way, compounded of a yearning for a more elemental life, a sense of adventure, and a need for some land of mystery where a man's romanticism can find play. It is surprising to find these feelings so often expressed, whether by young people or by aging corporate executives, and they account in some substantial measure for public attitudes about oil and the Arctic environment.

\section{NEW INITIATIVES IN THE NORTH}

These many concerns about the Arctic have already produced new legislation, although the setting remains one where new problems are being generated faster than solutions are being found, and as yet there is more talk about solutions than action. From the federal government we have John Naysmith's handsome presentation called Canada North-Man and the Land, ${ }^{2}$ in which he describes the new land-use programme for the north. Last year, the Parliament of Canada gave us the Arctic Waters Pollution Prevention Act, ${ }^{3}$ heralded as such a precedent-breaking move in the field of international law that Canada had to withdraw jurisdiction over the legislation from the International Court of Justice, but the Act has not yet been proclaimed in force. On the industry side there is the Environment Protection Board sponsored by the Gas Arctic Systems Study Group, which is publicizing pipeline problems in the north and the kinds of research necessary to solve them. The Arctic Institute of North America has established programmes dealing with Arctic Development and Environment (ADE) and Man in the North (MIN), the industry has its Arctic operators consortium, and conservation groups are beginning to articulate their concerns. At this seminar, there will be distributed copies of a special supplement to the U.B.C. Law Review ${ }^{4}$ which reports the resolutions and proceedings of an Arctic International Wildlife Range Conference held last fall in Whitehorse. A capsuled understanding of the proposed Wildlife Range would be an attempt by conservationists in Canada and the United States to enlist government and industry, as well as native peoples and other northerners, in an effort to give special thought and planning to a particularly interesting part of the Arctic-the northern tip of the Yukon and the northeastern corner of Alaska. The attempt seems to have gained considerable success, and a good deal more will be heard about the Wildlife Range in the future.

\footnotetext{
2 Information Canada, Ottawa, 1971, Cat. No. R72-6770.

3 S.C. $1969-70$, c. 47.

+ Vol. 6, No. 1, June, 1971.
} 


\section{THE JURISDICTIONAL FRAMEWORK IN THE NORTH}

Turning to the new legislation, one should first mention the different jurisdictional pattern in the north as compared with the south, where we are familiar with the mix of federal-provincial responsibilities. Unlike the position in the south, the federal government has exclusive jurisdiction over all natural resources except game in the Yukon and the Northwest Territories. This jurisdiction is reflected in the legislation dealing with mineral resources such as the Canada Oil and Gas Land Regulations, ${ }^{5}$ the Canada Mining Regulations ${ }^{6}$ and the Yukon Minerals Act, ${ }^{7}$ now before Parliament. The territorial governments have a like responsibility to that of provincial governments over privately-owned property and with respect to public works and undertakings in the northern communities, and therefore can regulate waste disposal and pollution from a public health and welfare point of view. For example, the Yukon Territorial Council can pass ordinances dealing with litter and other waste disposal anywhere in the Yukon in so far as they regulate human activity rather than the land or its resources. But. all jurisdiction of the Council derives from the Yukon Act, ${ }^{8}$ which is a statute of the Parliament of Canada, and therefore any enactment of the Council must ultimately give way to any inconsistent enactment of Parliament. For example, regulations properly made by the Governor in Council under a federal statute such as the Territorial Lands Act ${ }^{9}$ (which is the foundation of the Canada Oil and Gas Land Regulations) would likely override any inconsistent enactment of the Council, so that a federal oil and gas lessee would be bound to comply with waste disposal laws passed by the Council only to the extent that they are not inconsistent with federal drilling and production regulations and with the terms of the federal oil and gas lease. The Territorial Councils have not so far attempted, to my knowledge, to regulate the activities of oil and gas lessees and operators and are not likely to do so at the present. Should a Council attempt to regulate in this field, there is the federal power of disallowance exercisable through the Minister and the Commissioner which can be activated to eliminate inconsistencies and conflicts.

\section{E. FEDERAL ADMINISTRATION}

On the federal side, the Department of Indian Affairs and Northern Development has the chief administrative role. Other federal departments concerned with the northern environment have been the $\mathrm{De}$ partment of Fisheries and the Department of National Defence. Within DIAND, the Canadian Wildlife Service and the National and Historic Parks Branch have had special roles to play with respect to conservation. Now that the Canadian Wildlife Service has been transferred to the new federal Department of the Environment, it is likely that this department will assume some of the environmental responsibilities formerly discharged within DIAND, but it is still too early to have a clear picture of the division of administrative responsibilities between DIAND and the new Department of the Environment.

s SOR/61-253, see Lewis and Thompson, Canadian Oil and Gas, Vol. 6, Para. [4]

- SOR/61303.

7 An Act Respecting Minerals in the Yukon Territory, 3rd Sess., 28th Parl., 1970 Bill C-187.

- R.S.C. 1970 , c. Y.2.

- R.S.C. 1970, c. T-6. 


\section{F. ARCTIC WATERS POLLUTION PREVENTION ACT ${ }^{10}$}

Mr. Lewis will be dealing with the liability provisions of this new legislation in his paper entitled Legal Liability in the Canadian Arctic Relating to Oil Spills and Blowouts. ${ }^{11}$ My purpose in citing this Act is to point out the respects in which it authorizes the regulation of onshore and offshore drilling and exploration activities. It is abundantly clear that the Act applies to activities on land as well as to those that take place in the offshore areas. Section 6, in defining liability, expressly applies to "any person who is engaged in exploring for, developing or exploiting any natural resource on any land adjacent to the Arctic waters ...."The words "adjacent to the Arctic waters" are capable of either a wide or a narrow interpretation. Sections 4 and 10 refer to the deposit of waste in any place on the mainland where such waste may enter Arctic waters. In the widest sense waste deposited in any tributary of the Mackenzie River could ultimately enter Arctic waters, and the same result could be postulated with respect to waste deposited in any northward-flowing drainage system. If this drainage system test were to be used to determine the meaning of "land adjacent to the Arctic waters" it would mean that the pollution prevention provisions of the Act could be applied to drilling and producing operations almost anywhere in the Canadian North.

The key provision of the Act respecting such operations is section 10. It authorizes the Governor in Council to require any person who proposes to construct, alter or extend any works on the mainland or off-shore that could result in the deposit of waste in Arctic waters to provide the Governor in Council with a copy of plans and specifications relating to the work. After reviewing the plans and specifications, and affording the person an opportunity to be heard, the Governor in Council, if of opinion that the deposit of waste may occur, may either require modification of the plans and specifications or prohibit the carrying out of the works. Such cabinet control is not likely to be carried out as a routine form of administration. Rather, section 10 gives the Governor in Council enabling powers so that it may deal effectively with any major venture that is to be undertaken in the Arctic with attendant pollution problems.

\section{G. NORTHERN INLAND WATERS ACT'12}

This Act goes hand in hand with the new Canada Water Act ${ }^{13}$ to provide for a system of allocating water rights through licencing to ensure that all works and undertakings respecting water use, diversion, storage and treatment are designed and constructed to proper engineering standards, and to maintain the principle that a licence to use water is accompanied by an obligation on the user to return the water to the natural environment in a condition that meets acceptable water quality standards. The Act will ensure that this obligation is discharged by requiring adequate treatment facilities to be provided before a licence is granted. Water boards will be located in Whitehorse and Yellowknife with membership both from the federal government de-

\footnotetext{
10 S.C. 1969-70, c. 47; R.S.C. 1970, c. 2 (1st Supp.).

1I Infra, at 440 .

12 S.C. 1969 , c. 66; R.S.C. 1970, c. 28 (1st Supp.).

${ }^{23}$ S.C. 1969 , c. 52; R.S.C. 1970, c. 5 (1st Supp.).
} 
partments concerned with water resources and from the Territories. These boards will have responsibility for approving the issuance of licences and for setting the conditions designed to regulate water use and to maintain water quality standards. The boards may hold public hearings in discharging their responsibilities.

\section{H. TERRITORIAL LAND-USE REGULATIONS}

These regulations represent the main thrust of the programme of the Department of Indian Affairs and Northern Development to cope with the environment problems created by oil and mining activities in the north. The regulations were in the process of formulation for almost two years and were published in final form on November 24, $1971 .{ }^{14}$ In their planning stage, department officers consulted with an advisory board comprising representatives of the oil and mining industries, representatives of conservation groups and department personnel. ${ }^{15}$

Initially, it was proposed to divide the entire north into five regions, to require land-use permits for all land-use activities, and to design a set of permit stipulations which would be appropriate for each of the five regions. It soon became evident that it was unrealistic to attempt to create zones and permit stipulations in advance, and consequently, amendments to the Territorial Lands Act were passed during the 1969-1970 session of Parliament. ${ }^{16}$ These amendments authorized the making of regulations respecting the protection, control and use of the surface of territorial lands, ${ }^{17}$ made it clear that permittees and licensees under the Canada Oil and Gas Land Regulations and the Canada Mining Regulations would be subject to the new land-use regulations, ${ }^{18}$ and authorized the establishment of landmanagement zones and the making of regulations respecting the protection, control and use of the surface of land in these land-management zones through the issue of land-use permits. ${ }^{19}$

A new feature in relations between the federal and territorial governments is incorporated in these amendments by a requirement that the Governor in Council consult with councils of the Territories when designating land management zones and when making regulations respecting their use and the issue of permits. ${ }^{20}$ Such consultations were held by department officers in early 1971, resulting in many proposals for change from the councils. The report adopted by the Council of the Northwest Territories contains many constructive suggestions, particularly with reference to application of the draft regulations to the mining industry.

From the oil industry point of view, the Land-Use Regulations have their counterparts in the provinces in regulations governing geophysical operations. The definition of "land-use operation"21 itself has pro-

14 SOR/71-580, The Canada Gazette, Part II, No. 22, Vol. 105, at 1908; See Lewis and Thompson, Canadian Oil and Gas, Vol. 6, Para. [3E].

15 The writer was a member of this advisory group and contributed to the drafting of the regulations in the initial stages.

16 An Act to amend the Yukon Act, the Northwest Territories Act and the Territorial Lands Act, S.C. 1969-70, c. 69 .

17 Id. в. 25.

18 Id. 3.27.

19 Id. s. 24.

${ }^{20} \mathrm{Id}$.

21 SOR/71-580, в. 2. 
vided much discussion in the formulation of the regulations, because this definition will draw the line between those uses of the surface that will be regulated and those that will not. Part I of the regulations provides a sort of code of good behaviour for all those who conduct land use operations. Part II introduces the permit system whereby operations in the land management zones may be more closely regulated. This regulation may include inspection before the issue of a permit and the designation of special conditions that will apply to the operations. ${ }^{22}$ Section 21 sets out the kinds of conditions that may be imposed in the permit. A quick glance at the section will indicate that they can have serious impact on the carrying out of a land use operation. There are provisions for a guaranteed deposit ${ }^{23}$ and for cancellation of the land use permit in the event of failure to comply with the terms and conditions of the permit or with the regulations. ${ }^{24}$ A system of appeals from any decision, direction or order given by the engineer is provided for in Part III.

\section{OIL AND GAS PRODUCTION AND CONSERVATION}

The land-use regulations are intended to cover use of the surface in all exploration phases of the oil industry prior to the actual drilling of a well. The drilling operation is intended to be governed by the terms and conditions of the oil and gas permit or lease and by the provisions of the Canada Oil and Gas Drilling and Production Regulations. ${ }^{25}$ These regulations were made under the Territorial Lands Act. Now that Parliament has enacted the Oil and Gas Production and Conservation Act, ${ }^{26}$ which received Royal assent on June 11, 1970, a new set of drilling and production regulations is being prepared for promulgation under this Act. Since section 12 of the Act gives the Governor in Council power to make regulations "prescribing the measures necessary to prevent pollution of air, land or water as a result of the exploration and drilling for ... . any oil or gas", it is likely that these new regulations will contain pollution prevention requirements as stringent as those provided in the land use regulations.

\section{J. IS THERE A NEW ENVIRONMENTAL LAW?}

It is true that in most respects there is nothing new about the demands being made on law and on lawyers in the name of pollution and the environment. The clamour is for more statutes, by-laws and regulations restricting the use of land, stricter enforcement of these laws, stiffer penalties, and more taxes against polluters. If there is a new preoccupation in environmental law, it reaches deeply into the decision-making processes in modern society. There seems to be a consensus that it is no longer appropriate to have decisions about the use of the environment made exclusively as business decisions or resource-utilization decisions. Rather, the values at stake are seen to reach beyond questions of return on the dollar invested and to require an accounting of a wide range of detriments and benefits external to

\footnotetext{
22 Id. s. 19.

23 Id. s. 26.

${ }^{24}$ Id. 8.33.

25 SOR/61-253.

28 R.S.C. 1970 , c. $0-4$.
} 
the particular project. If these new values are to be considered, new forms of representation in the decision-making process are required. It seems to me that it is at this point that a new environmental law is taking shape. If I am right in this respect, this new environmental law has great implications for the lawyer and will involve him more and more deeply in environmental problems.

This search for new systems of representation is already evident in the new initiatives being taken to protect the northern environment. I have mentioned the requirement that the Territorial Councils be consulted in the regulation-making process. I have mentioned the new water boards and their powers to hold public hearings. The new Canada Clean Air Act provides for the establishment of advisory committees and for a 60-day notice period in the Canada Gazette before national pollution standards are promulgated. Requests were made to the Minister of Indian Affairs and Northern Development to establish an advisory board with respect to the new land use regulations, and one of the thornier problems in developing the regulations was a strong bid to have some kind of hearing procedure prior to the issue of land-use permits so that affected persons might be heard in opposition to the issuance of the permit.

Through press reports we are all familiar with the hearings which were held in Washington and in Anchorage with respect to the Alaska pipeline system. What is not so well known is that the National Environmental Quality Act of $1969^{27}$ requires that an environmental impact statement be prepared with respect to every project that may have substantial impact on the environment in the United States. These statements are to be circulated in draft form to other government agencies and to the public so that they may be studied and criticized. In many cases, federal laws require that public hearings be held prior to the authorization of such projects, and in these cases the environmental impact statement will provide the framework for these public hearings. Just such public hearings are those that have been delaying pipeline construction in Alaska. David Anderson, the Member of Parliament for Esquimalt-Saanich, has recently been quoted as recommending similar environmental impact statement laws for Canada, and he has said that no pipeline authorizations should be given in the north without such impact statements and public hearings.

It is my opinion that these demands for public participation and for a broad range of inquiries with respect to undertakings such as the commencement of off-shore drilling, the laying of pipelines, and the construction of processing plants and other like facilities will grow in Canada and that our course will follow the United States' pattern. Along with this demand in the United States there have been substantial developments in the law which have given the private litigant opportunity to make his voice heard in the decision-making process about use of the environment. ${ }^{28}$ These developments have given the private citizen standing to sue in court, sometimes in the name of a public trust doctrine, to ensure that government agencies are discharging their duties of investigation and inquiry before granting authorizations and

\footnotetext{
27 Public Law 91-190.

2s Joseph L. Sax, Emerging Legal Strategies: Judicial Intervention, May, 1970, Vol. 389, Annals of the American Academy of Political and Social Science, 71 at 72.
} 
permits. Again, it is likely that our courts will respond more generously to this kind of litigation. The consequence is that the oil industry lawyer will have to become well versed in the dialectic of the environmentalists and in the legislative regime governing use of resources so that he can represent his client in the new forums of tomorrow. 